\title{
Geochemical and Petrographic Data for Intrusions Peripheral to the Big Timber Stock, Crazy Mountains, Montana
}

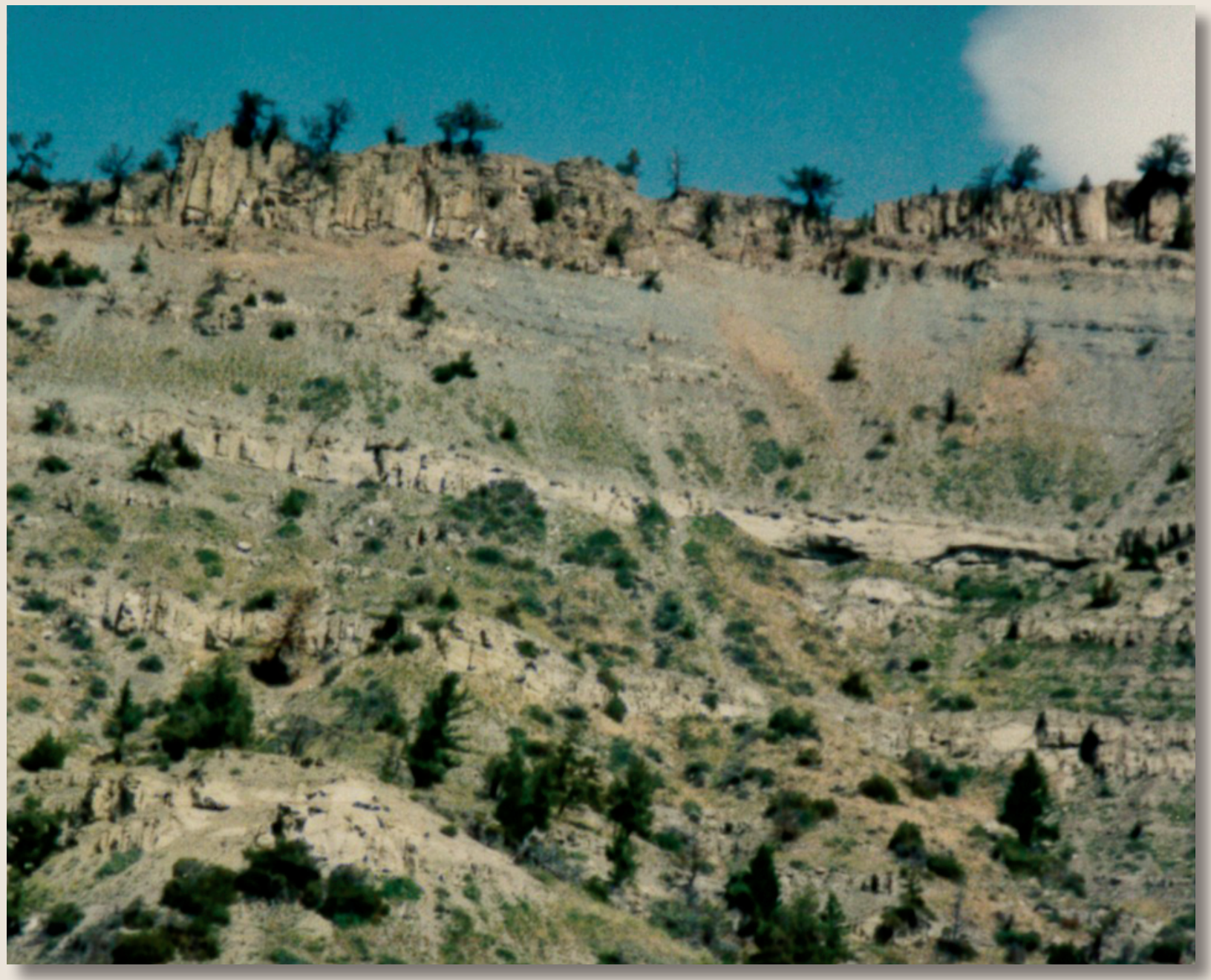

Data Series 895 
COVER. Prominent Eocene sill along the ridge crest, above rocks of the Fort Union Formation, 4 kilometers northeast of Gobblers Knob, Montana. (Photo by Anna B. Wilson, U.S. Geological Survey, 1992.) 


\section{Geochemical and Petrographic Data for Intrusions Peripheral to the Big Timber Stock, Crazy Mountains, Montana}

By Edward A. du Bray, Anna B. Wilson, and Bradley S. Van Gosen

Data Series 895 


\section{U.S. Department of the Interior \\ SALLY JEWELL, Secretary}

\section{U.S. Geological Survey \\ Suzette M. Kimball, Acting Director}

\section{U.S. Geological Survey, Reston, Virginia: 2015}

For more information on the USGS - the Federal source for science about the Earth, its natural and living resources, natural hazards, and the environment, visit http://www.usgs.gov or call 1-888-ASK-USGS.

For an overview of USGS information products, including maps, imagery, and publications, visit http://www.usgs.gov/pubprod

To order this and other USGS information products, visit http://store.usgs.gov

Any use of trade, firm, or product names is for descriptive purposes only and does not imply endorsement by the U.S. Government.

Although this information product, for the most part, is in the public domain, it also may contain copyrighted materials as noted in the text. Permission to reproduce copyrighted items must be secured from the copyright owner.

Suggested citation:

du Bray, E.A., Wilson, A.B., and Van Gosen, B.S., 2015, Geochemical and petrographic data for intrusions peripheral to the Big Timber stock, Crazy Mountains, Montana: U.S. Geological Survey Data Series 895, 19 p., http://dx.doi.org/10.3133/ds895.

ISSN 2327-638X (online) 


\section{Contents}

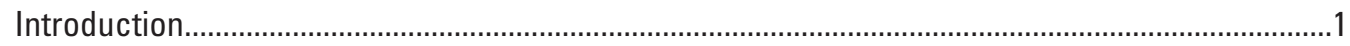

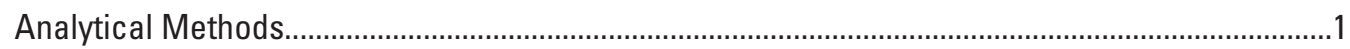

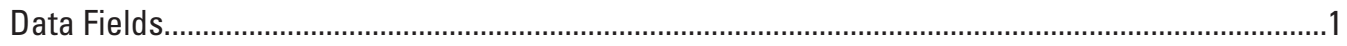

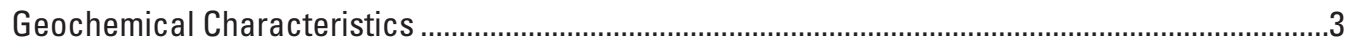

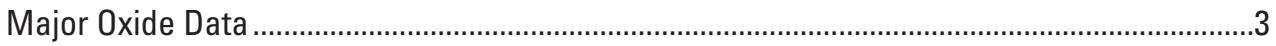

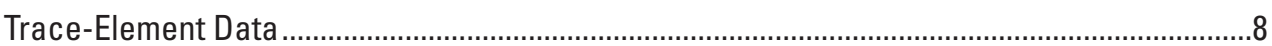

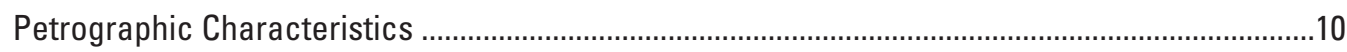

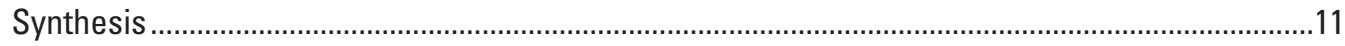

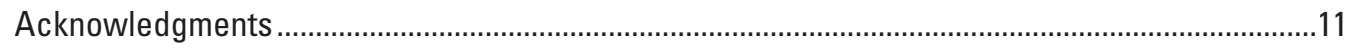

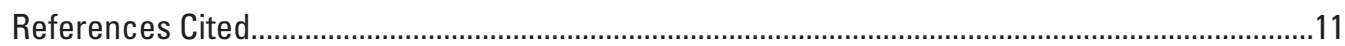

Appendix 1. Status and Treatment of Samples of Sills and Plugs Peripheral to the

Big Timber Stock, Crazy Mountains, Montana ........................................................................14

Appendix 2. Geochemical and Petrographic Data for Samples of Sills and Plugs

Peripheral to the Big Timber Stock, Crazy Mountains, Montana.....

\section{Figures}

1. Regional geologic setting for the Crazy Mountains, Montana, showing the Big Timber stock, associated radial dikes, and peripheral sills and plugs

2. Variation diagram showing relative alumina and alkali saturation of igneous rocks peripheral to the Big Timber stock, Crazy Mountains, Montana, as a function of molar major-oxide compositions.

3. Variation diagram showing $\mathrm{FeO} /(\mathrm{FeO}+\mathrm{MgO})$ values for igneous rocks peripheral to the Big Timber stock, Crazy Mountains, Montana, relative to boundaries between ferroan and magnesian rocks.

4. Total alkali-silica variation diagram showing compositions of igneous rocks peripheral to the Big Timber stock, Crazy Mountains, Montana

5. Variation diagram showing $\mathrm{Na}_{2} \mathrm{O}+\mathrm{K}_{2} \mathrm{O}-\mathrm{CaO}$ values versus $\mathrm{SiO}_{2}$ content among samples of igneous rocks peripheral to the Big Timber stock, Crazy Mountains, Montana

6. Variation diagrams showing abundances of major oxides in igneous rocks peripheral to the Big Timber stock, Crazy Mountains, Montana .........................................9

7. Trace-element, tectonic setting-discrimination variation diagram showing the composition of igneous rocks peripheral to the Big Timber stock, Crazy Mountains, Montana. 


\section{Tables}

1. Definition and characterization of data fields included in appendix 1 (status and treatment of samples)...

2. Definition and characterization of data fields included in appendix 2 (geochemical and petrographic data)

\section{Abbreviations}

\begin{tabular}{|c|c|}
\hline $\mathrm{Al}_{2} \mathrm{O}_{3}$ & aluminum oxide \\
\hline$A m$ & americium \\
\hline $\mathrm{Ba}$ & barium \\
\hline $\mathrm{CaO}$ & calcium oxide \\
\hline $\mathrm{Cd}$ & cadmium \\
\hline $\mathrm{Ce}$ & cerium \\
\hline $\mathrm{FeO}$ & ferrous iron \\
\hline K & potassium \\
\hline $\mathrm{K}_{2} \mathrm{O}$ & potassium oxide \\
\hline $\mathrm{La}$ & lanthanum \\
\hline $\mathrm{MgO}$ & magnesium oxide \\
\hline $\mathrm{MnO}$ & manganese oxide \\
\hline $\mathrm{Na}_{2} \mathrm{O}$ & sodium oxide \\
\hline $\mathrm{Nb}$ & niobium \\
\hline $\mathrm{Nd}$ & neodymium \\
\hline $\mathrm{P}_{2} \mathrm{O}_{5}$ & phosphorus pentoxide \\
\hline $\mathrm{Rb}$ & rubidium \\
\hline $\mathrm{SiO}_{2}$ & silicon dioxide \\
\hline $\mathrm{Sr}$ & strontium \\
\hline $\mathrm{TiO}_{2}$ & titanium dioxide \\
\hline Y & yttrium \\
\hline $\mathrm{Zr}$ & zirconium \\
\hline ppm & parts per million \\
\hline
\end{tabular}




\title{
Geochemical and Petrographic Data for Intrusions Peripheral to the Big Timber Stock, Crazy Mountains, Montana
}

\author{
By Edward A. du Bray, Anna B. Wilson, and Bradley S. Van Gosen
}

\section{Introduction}

In the Crazy Mountains of south-central Montana, the Paleocene Fort Union Formation hosts a compositionally diverse array of Eocene plugs, dikes, and sills arrayed around the Eocene Big Timber stock; all of these rocks are part of the Crazy Mountains magmatic system. As documented by du Bray and Harlan (1996) and Dudas (1990, 1991), Eocene igneous rocks in the Crazy Mountains include silicaundersaturated, strongly alkaline intrusive rocks and silicasaturated, alkaline to subalkaline intrusive rocks that are approximately coeval. Most of the strongly alkaline rocks are in the northern part of the Crazy Mountains and form sills, laccoliths, small stocks, and dikes. The strongly alkaline plug at Ibex Mountain (fig. 1) is located significantly farther south than other strongly alkaline rocks associated with the Crazy Mountains magmatic system. Compositionally less exotic alkaline to subalkaline rocks, including constituents of the Big Timber stock (du Bray and Harlan, 1996), form stocks and associated dike swarms that are mostly restricted to the southern part of the range (fig. 1). Other Eocene intrusions, including outcrops at Gobblers Knob, Raspberry Butte, and other nearby conformable intrusions form a set of sills that are satellitic to the Big Timber stock and constitute a third, relatively unstudied set of intrusions in the Crazy Mountains (fig. 1).

The distribution of intrusive rocks in the Crazy Mountains is portrayed on various geologic maps of the area, including those by Wolff (1938), Simms (1966), Tappe (1966), Starmer (1972), and du Bray and others (1993). The petrology and petrogenesis of the strongly alkaline rocks in particular were well documented by Dudas (1990, 1991). Subsequently, du Bray and Harlan (1996) conducted a detailed investigation concerning the petrogenesis of the Big Timber stock, and du Bray and others (2006) characterized the radial dike swarm associated with the Big Timber stock. None of these studies, however, have documented and synthesized the geochemistry and petrography of the sills that are peripheral to the Big Timber stock.

The purpose of this report is (1) to present available geochemical and petrographic data for several dozen igneous rock samples, which represent sills and plugs peripheral to the Big Timber stock, and (2) to provide a basic interpretive synthesis of these data. These samples were collected in 1992 during geologic mapping of the Big Timber stock by du Bray and others (1993). During field studies, 28 outcrop samples were collected for subsequent laboratory analysis. Petrographic data were acquired for 25 of these samples, and geochemical analyses were acquired for 26 of these samples. Five samples of strongly alkaline rock, four from the plug at Ibex Mountain and one from a small plug exposed along the Shields River northwest of the Big Timber stock, are petrographically and geochemically distinct relative to all other samples described herein.

\section{Analytical Methods}

Petrographic characteristics of samples were determined using a standard petrographic microscope. All whole-rock major oxide chemical abundances were determined by wavelength-dispersive X-ray fluorescence spectrometry, using methods described by Taggart and others (1987), in analytical laboratories of the U.S. Geological Survey, Denver, Colorado. All iron abundances were converted to ferrous iron, and each major oxide analysis was recalculated to 100 percent on a volatile-free basis. Trace-element abundances were determined by energy-dispersive X-ray fluorescence spectroscopy (Elsass and du Bray, 1982; Yager and Quick, 1992) using ${ }^{109} \mathrm{Cd}$ and ${ }^{241}$ Am radio-isotope excitation sources. All censored values were replaced by blank cells; for lower limits of determination, see Elsass and du Bray (1982).

\section{Data Fields}

Data were compiled using Microsoft Excel; they are presented here in two appendixes, found both at the back of this report and as Excel files (Appendix1.xlsx and Appendix2.xlsx) linked from this document and from http://dx.doi. org/10.3133/ds895. The files can be accessed using software 


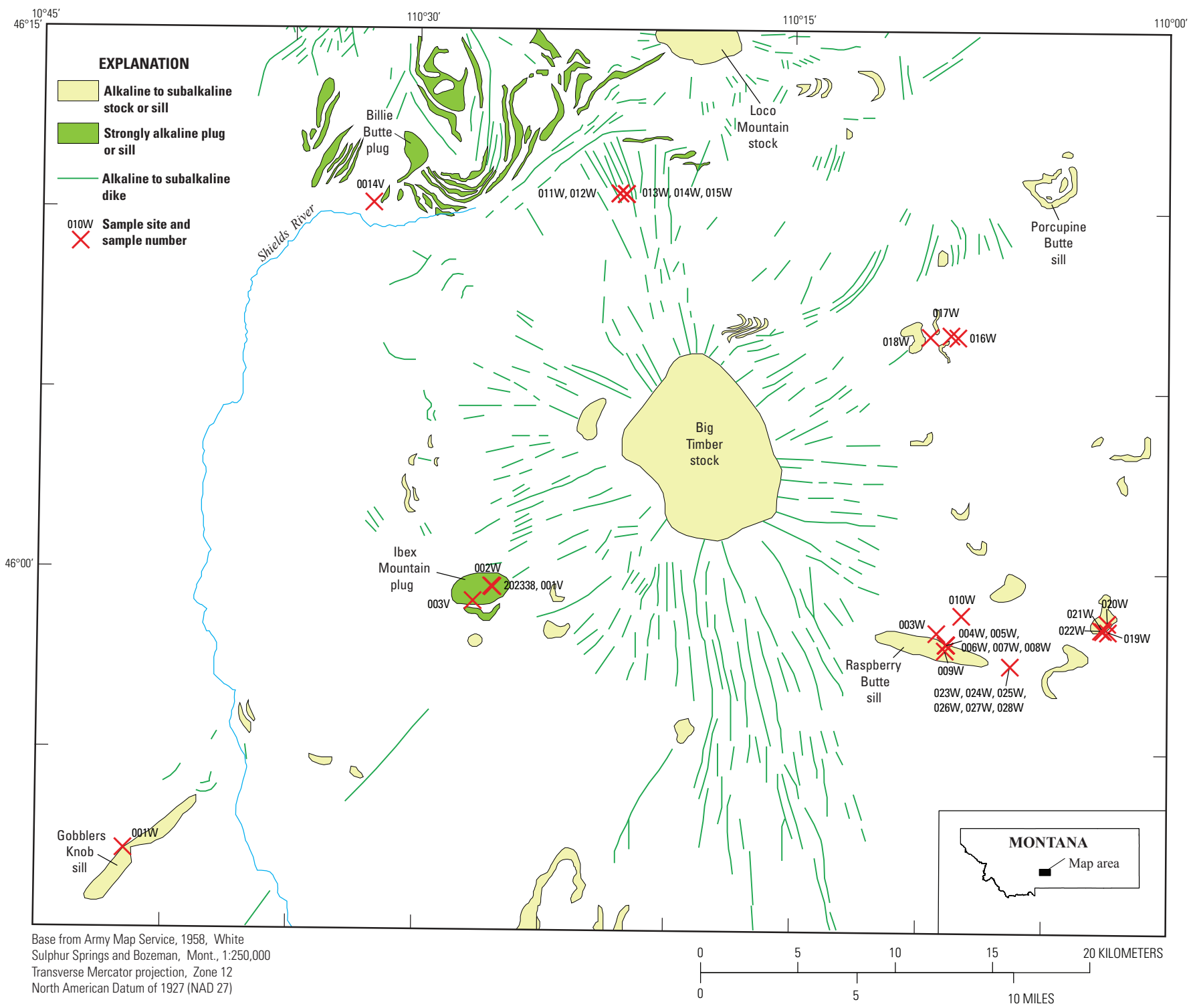

Figure 1. Regional geologic setting for the Crazy Mountains, Montana, showing the Big Timber stock, associated radial dikes, and peripheral sills and plugs. Collection sites for all samples described herein are labelled; complete sample numbers for samples ending in "V" or "W" include the suffix "92." Geologic features modified from Roberts (1972). (Click here to open fullsize, high-resolution image.) 
compatible with the .xlsx file format. Sample characterization, geochemical, and petrographic data are presented in columns or sets of related columns. The contents of appendix 1 constitute basic sample information, including sample location, sample treatment, and lithologic characterization for each sample; see table 1 for data field definitions. Appendix 2 contains geochemical and petrographic observations; see table 2 for data field definitions. Geochemical data in some worksheet cells might appear to be more precise than displayed values, but the implied precision is a misleading artifact of computational processes used to create data-cell contents (for instance, recalculation to 100-percent volatile free). Blank cells in the appendix worksheets indicate either null values or that no data are available. In appendix 2, some blank cells reflect abundances that were reported as "less than the lower limit of determination for the analytical method used;" these values were replaced by blank cells to enable statistical analysis of the uncensored data.

\section{Geochemical Characteristics}

\section{Major Oxide Data}

As is true of the Big Timber stock and its associated radial dike swarm (du Bray and Harlan, 1996; du Bray and others, 2006), major oxide characteristics of the sill-forming rocks peripheral to the Big Timber stock are consistent with a subduction-related petrogenesis. Compositions of three samples of the Ibex Mountain plug and one sample from a plug along the Shields River are quite distinct and are described separately. Relative to standard metrics (in cited sources), the sill-forming rocks are metaluminous (fig. 2) (Shand, 1951), magnesian (fig. 3) (Frost and others, 2001), and have compositions (fig. 4) that straddle the alkaline-subalkaline dividing line of Irvine and Baragar (1971). In terms of the balance between abundances of $\mathrm{CaO}, \mathrm{Na}_{2} \mathrm{O}$, and $\mathrm{K}_{2} \mathrm{O}$ in these rocks, the sill compositions vary significantly across the entire calcic, calcalkalic, alkali-calcic, and alkalic spectrum (fig. 5), likely a misleading consequence of post-magmatic alteration and alkali mobility experienced by these rocks. Abundances of $\mathrm{SiO}_{2}$ in the sill-forming rocks range nearly continuously from about 46 to 63 weight percent (fig. 4), and their compositions range from basalt to dacite and their alkaline analogs. Concentrations of $\mathrm{TiO}_{2}$ and $\mathrm{MgO}$ vary considerably at lower $\mathrm{SiO}_{2}$ abundances but scatter less and decrease to lower values at higher $\mathrm{SiO}_{2}$ contents (fig. 6). Concentrations of $\mathrm{FeO}^{*}$ (total iron, expressed in the ferrous state), $\mathrm{MnO}$, and $\mathrm{CaO}$ (fig. 6) decrease in a linear fashion with increasing $\mathrm{SiO}_{2}$. Abundances of $\mathrm{Na}_{2} \mathrm{O}$ and $\mathrm{P}_{2} \mathrm{O}_{5}$ vary widely and yield no consistent variation relative to $\mathrm{SiO}_{2}$ content. Abundances of $\mathrm{Al}_{2} \mathrm{O}_{3}$ and $\mathrm{K}_{2} \mathrm{O}$ increase broadly with increasing $\mathrm{SiO}_{2}$ content; the $\mathrm{K}_{2} \mathrm{O}$ data array is dominated by transitional high-potassium to shoshonitic compositions (Gill, 1981). These trends and compositional ranges are similar to and overlap those of the Big Timber stock and its associated radial dike swarm (du Bray and Harlan, 1996; du Bray and others, 2006).

Primary mafic magmas that assimilate crustal contaminants predictably evolve to more silicic compositions characterized by progressively lower $\mathrm{P}_{2} \mathrm{O}_{5} / \mathrm{K}_{2} \mathrm{O}$ because crustal materials generally have $\mathrm{P}_{2} \mathrm{O}_{5} / \mathrm{K}_{2} \mathrm{O}$ less than 0.1 (Farmer and others, 2002). Among the sill-forming rocks, $\mathrm{P}_{2} \mathrm{O}_{5} / \mathrm{K}_{2} \mathrm{O}$ decreases with increasing $\mathrm{SiO}_{2}$ content and increases with increasing $\mathrm{MgO}$ content, which suggests that compositions of the magmas represented by these rocks evolved through variable contamination of primary mafic partial melts by crustally derived inputs. Similarly, Cousens and others (2008) suggested that decreasing $\mathrm{CaO} / \mathrm{Al}_{2} \mathrm{O}_{3}$ with increasing $\mathrm{SiO}_{2}$ principally reflects crustal contamination. Among the sillforming rocks, $\mathrm{CaO} / \mathrm{Al}_{2} \mathrm{O}_{3}$ decreases with increasing $\mathrm{SiO}_{2}$, which corroborates the influence of progressive crustal contamination in the development of these rocks.

Table 1. Definition and characterization of data fields included in appendix 1 (status and treatment of samples).

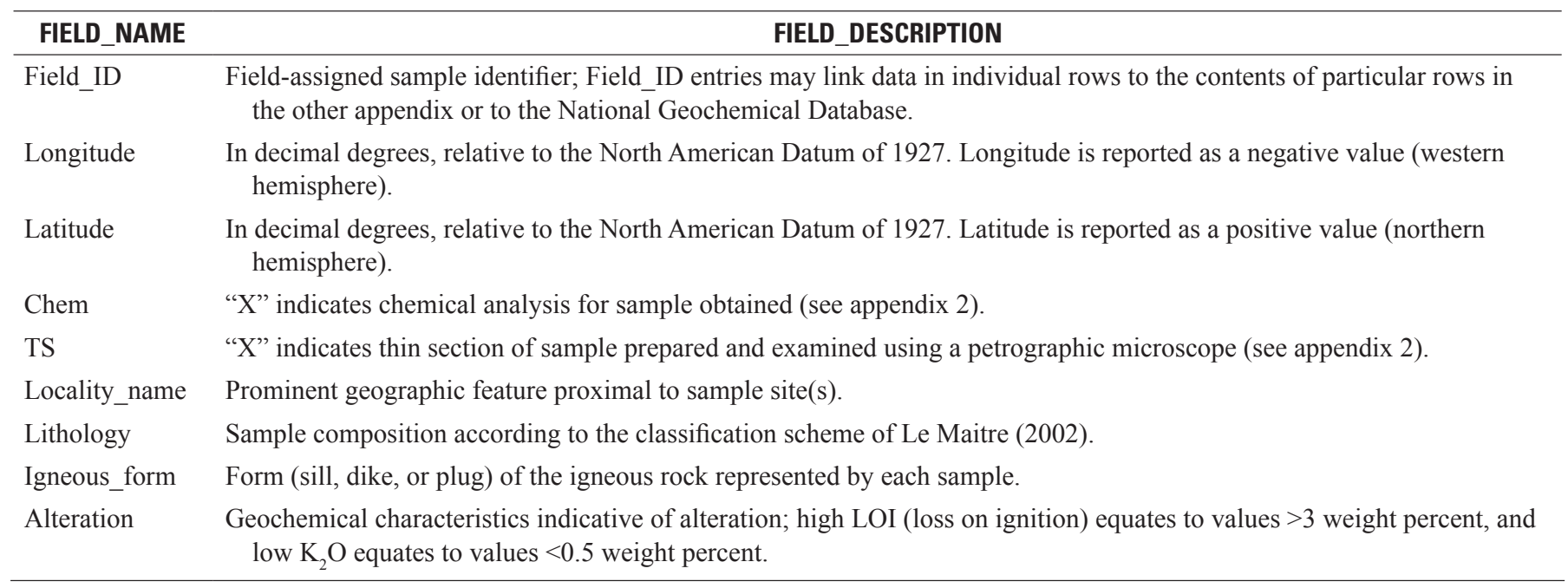


Table 2. Definition and characterization of data fields included in appendix 2 (geochemical and petrographic data).

FIELD_NAME

Field_ID

Locality_name

$\mathrm{SiO} 2$ pct

$\mathrm{TiO} 2 \_$pet

A12O3_pct

$\mathrm{FeO}^{*} \_$pct

$\mathrm{MnO}$ pet

$\mathrm{MgO} \_$pct

$\mathrm{CaO} \_$pct

$\mathrm{Na2O}$ pct

K2O_pct

P2O5_pct

LOI_pct

Total_I_pct

Ba_ppm

$\mathrm{Rb} \_p p m$

Sr_ppm

Y_ppm

$\mathrm{Zr}$ _ppm

$\mathrm{Nb} \_p p m$

Th_ppm

Ga_ppm

La_ppm

Ce_ppm

Nd_ppm

$\mathrm{Cu} \_$ppm

$\mathrm{Pb} \_p p m$

Zn_ppm

Sn_ppm

W_ppm

As_ppm

$\mathrm{Sb} \_p p m$

Abd Pl phenos

Abd_GrnAmph_phenos

\section{FIELD_DESCRIPTION}

Field-assigned sample identifier; Field_ID entries may link data in individual rows to the contents of particular rows in the other appendix or to the National Geochemical Database.

Prominent geographic feature proximal to sample site(s).

Silicon, as silicon dioxide, in weight percent; based on major oxide data recalculated to 100 percent on a volatile-free basis.

Titanium, as titanium dioxide, in weight percent; based on major oxide data recalculated to 100 percent on a volatile-free basis.

Aluminum, as aluminum trioxide, in weight percent; based on major oxide data recalculated to 100 percent on a volatile-free basis.

Total iron, as ferrous oxide, in weight percent; based on major oxide data recalculated to 100 percent on a volatile-free basis.

Manganese, as manganese oxide, in weight percent; based on major oxide data recalculated to 100 percent on a volatile-free basis.

Magnesium, as magnesium oxide, in weight percent; based on major oxide data recalculated to 100 percent on a volatile-free basis.

Calcium, as calcium oxide, in weight percent; based on major oxide data recalculated to 100 percent on a volatile-free basis.

Sodium, as sodium oxide, in weight percent; based on major oxide data recalculated to 100 percent on a volatile-free basis.

Potassium, as potassium oxide, in weight percent; based on major oxide data recalculated to 100 percent on a volatile-free basis.

Phosphorus, as phosphorus pentoxide, in weight percent; based on major oxide data recalculated to 100 percent on a volatile-free basis.

Volatile content lost on ignition, in weight percent.

Initial, pre-recalculation sum of oxide abundances, in weight percent.

Barium, in parts per million.

Rubidium, in parts per million.

Strontium, in parts per million.

Yttrium, in parts per million.

Zirconium, in parts per million.

Niobium, in parts per million.

Thorium, in parts per million.

Gallium, in parts per million.

Lanthanum, in parts per million.

Cerium, in parts per million.

Neodymium, in parts per million.

Copper, in parts per million.

Lead, in parts per million.

Zinc, in parts per million.

Tin, in parts per million.

Tungsten, in parts per million.

Arsenic, in parts per million.

Antimony, in parts per million.

Modal abundance of plagioclase phenocrysts relative to the whole rock, in volume percent.

Modal abundance of green amphibole (magnesio-hornblende) phenocrysts relative to the whole rock, in volume percent. 
Table 2. Definition and characterization of data fields included in appendix 2 (geochemical and petrographic data).-Continued

\section{FIELD NAME}

Abd_BrnAmph_ph
Abd_Bt_phenos
Abd_Cpx_phenos
Abd_Ol_phenos
Abd_Opq
TotXtls
ClrIndx
AgsPl
AgsGrnAmph
AgsBrnAmph
AgsBt
AgsCpx
AgsOl
AgsOpq
MgsPl
MgsGrnAmph
MgsBrnAmph
MgsBt
MgsCpx
MgsOpq

Texture

Access_Mnrls

XIP1

XlGrnAmph

XlBrnAmph

XIBt

XlCpx

$\mathrm{X} 1 \mathrm{Ol}$

X1Opq

\section{FIELD_DESCRIPTION}

Modal abundance of brown amphibole (magnesio-hastingsite) phenocrysts relative to the whole rock, in volume percent.

Modal abundance of biotite phenocrysts relative to the whole rock, in volume percent- $\mathrm{TR}$, trace amounts $(<0.5$ volume percent).

Modal abundance of clinopyroxene phenocrysts relative to the whole rock, in volume percent.

Modal abundance of olivine phenocrysts relative to the whole rock, in volume percent - TR, trace amounts $(<0.5$ volume percent).

Modal abundance of opaque iron-titanium oxide minerals relative to the whole rock, in volume percent.

Microscope-based estimate of total phenocryst content relative to the whole rock, in volume percent.

Microscope-based estimate of color index (sum of the abundances of hornblende, biotite, pyroxene, olivine, and opaque iron-titanium oxide minerals), in volume percent.

Microscope-based estimate of average grain size of plagioclase phenocrysts, in millimeters.

Microscope-based estimate of average grain size of green amphibole (magnesio-hornblende) phenocrysts, in millimeters.

Microscope-based estimate of average grain size of brown amphibole (magnesio-hastingsite) phenocrysts, in millimeters.

Microscope-based estimate of average grain size of biotite phenocrysts, in millimeters.

Microscope-based estimate of average grain size of clinopyroxene phenocrysts, in millimeters.

Microscope-based estimate of average grain size of olivine phenocrysts, in millimeters.

Microscope-based estimate of average grain size of opaque iron-titanium oxide phenocrysts, in millimeters.

Microscope-based estimate of maximum grain size (length) of largest plagioclase phenocryst, in millimeters.

Microscope-based estimate of maximum grain size (length) of largest green amphibole (magnesiohornblende) phenocryst, in millimeters.

Microscope-based estimate of maximum grain size (length) of largest brown amphibole (magnesiohastingsite) phenocryst, in millimeters.

Microscope-based estimate of maximum grain size (length) of largest biotite phenocryst, in millimeters.

Microscope-based estimate of maximum grain size (length) of largest clinopyroxene phenocryst, in millimeters.

Microscope-based estimate of maximum grain size (length) of largest olivine phenocryst, in millimeters.

Microscope-based estimate of maximum grain size (length) of largest opaque iron-titanium oxide phenocryst, in millimeters.

Characteristic petrographic textures as determined by microscopic observation-Aph, aphanitic; Hy, hyalophitic; Hc, holocrystalline; I, intersertal; E, equigranular; P, porphyritic; S, seriate; T, trachytic.

Accessory minerals identified by microscopic observation; listed in order of decreasing abundanceAp, apatite; Ttn, titanite.

Microscope-based estimate of crystallinity of plagioclase phenocrysts-A, anhedral; S, subhedral; E, euhedral.

Microscope-based estimate of crystallinity of green amphibole (magnesio-hornblende) phenocrystsA, anhedral; S, subhedral; E, euhedral.

Microscope-based estimate of crystallinity of brown amphibole (magnesio-hastingsite) phenocrystsA, anhedral; S, subhedral; E, euhedral.

Microscope-based estimate of crystallinity of biotite phenocrysts - A, anhedral; S, subhedral; E, euhedral.

Microscope-based estimate of crystallinity of clinopyroxene phenocrysts - A, anhedral; S, subhedral; $\mathrm{E}$, euhedral. If more than one crystallinity type is present, the dominant form is listed first.

Microscope-based estimate of crystallinity of olivine phenocrysts-A, anhedral; S, subhedral; E, euhedral.

Microscope-based estimate of crystallinity of opaque iron-titanium oxide phenocrysts - A, anhedral; $\mathrm{S}$, subhedral; E, euhedral. 
Table 2. Definition and characterization of data fields included in appendix 2 (geochemical and petrographic data).- - Continued

FIELD_NAME

Petrog_Com

$\mathrm{HblClr}$

AltExtnt

\section{FIELD DESCRIPTION}

Groundmass characteristics and otherwise noteworthy features. Groundmass minerals include plagioclase $(\mathrm{Pl})$, hornblende $(\mathrm{Hbl})$, clinopyroxene $(\mathrm{Cpx})$, biotite $(\mathrm{Bt})$, quartz $(\mathrm{Qtz})$, and opaque iron-titanium minerals $(\mathrm{Opq})$. The presence of secondary, alteration minerals, including chlorite $(\mathrm{Chl})$, calcite $(\mathrm{Cc})$, or epidote (Ep), is noted. [\%, percent; mm, millimeters] Pleochroic colors of hornblende phenocrysts, if present.

Microscope-based estimate of the extent of alteration - 1 indicates a completely fresh sample, and 5 indicates a completely altered sample in which primary textures and minerals are not identifiable. Intermediate values of 2 through 4 identify progressively more altered samples.

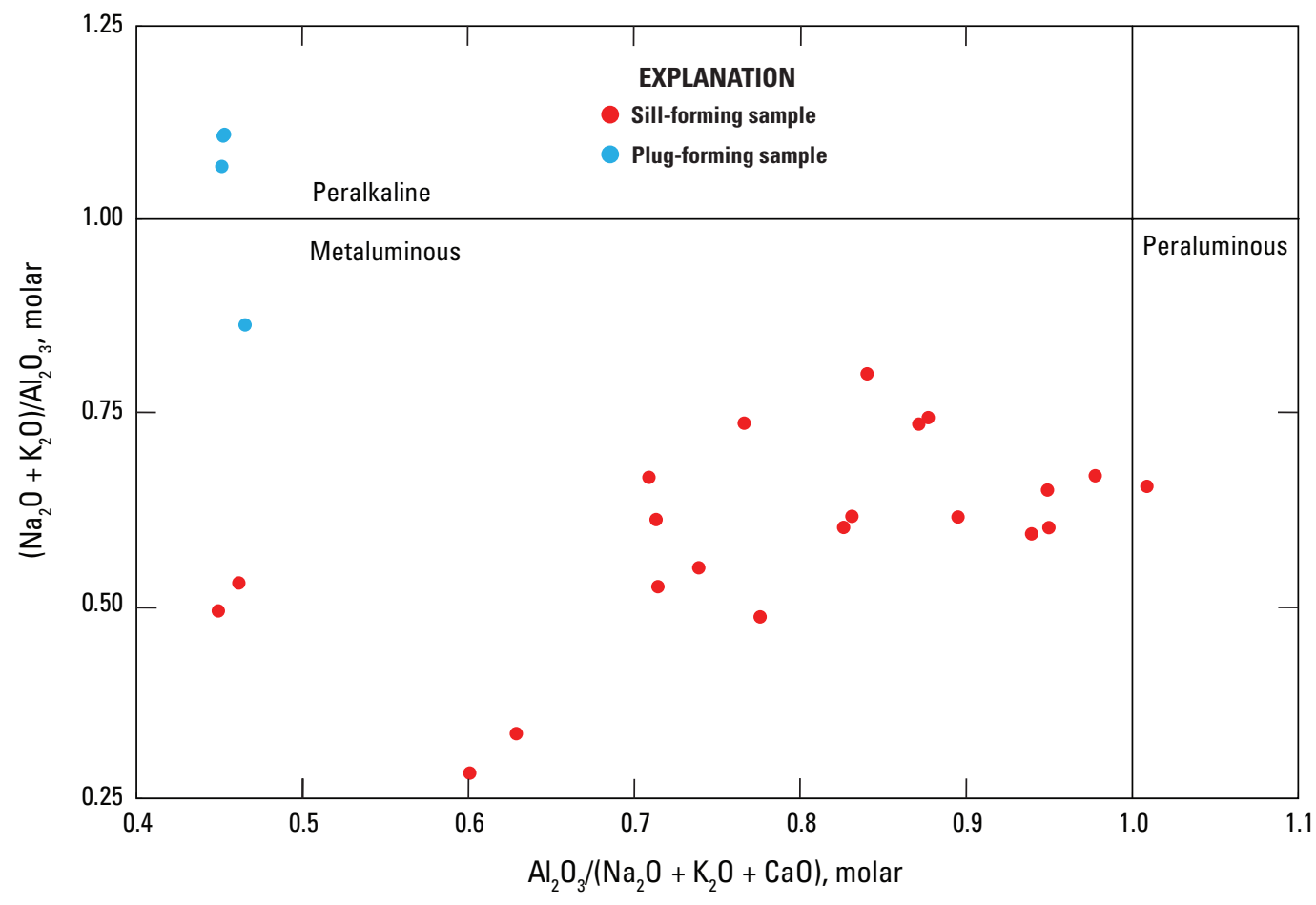

Figure 2. Variation diagram showing relative alumina and alkali saturation of igneous rocks peripheral to the Big Timber stock, Crazy Mountains, Montana, as a function of molar major-oxide compositions. 


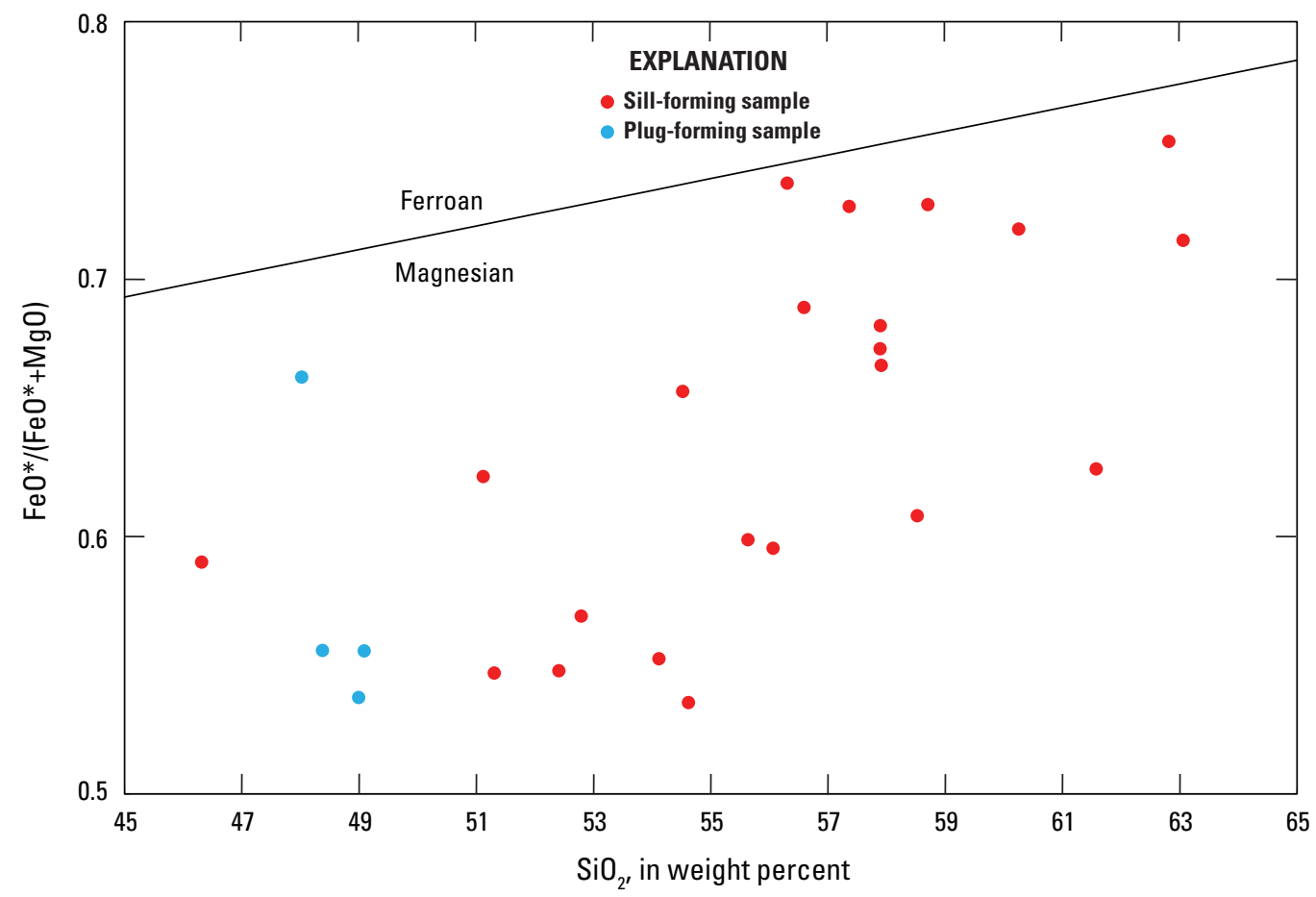

Figure 3. Variation diagram showing $\mathrm{FeO} /(\mathrm{Fe} 0+\mathrm{MgO})$ values for igneous rocks peripheral to the Big Timber stock, Crazy Mountains, Montana, relative to boundaries between ferroan and magnesian rocks. Ferroan-magnesian boundary from Frost and others (2001).

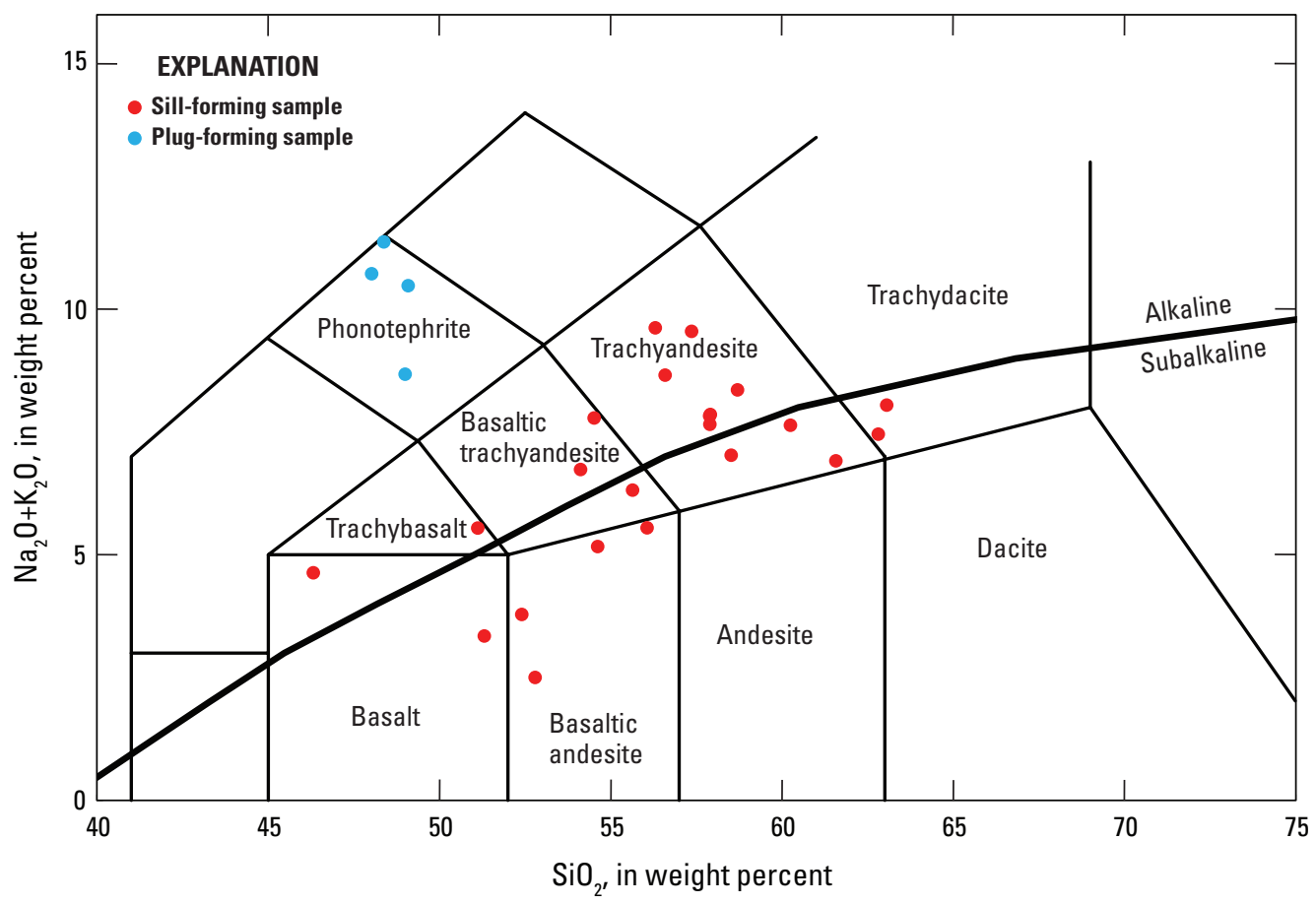

Figure 4. Total alkali-silica variation diagram showing compositions of igneous rocks peripheral to the Big Timber stock, Crazy Mountains, Montana. Field boundaries from Le Maitre (2002). Alkalinesubalkaline dividing line from Irvine and Baragar (1971). 


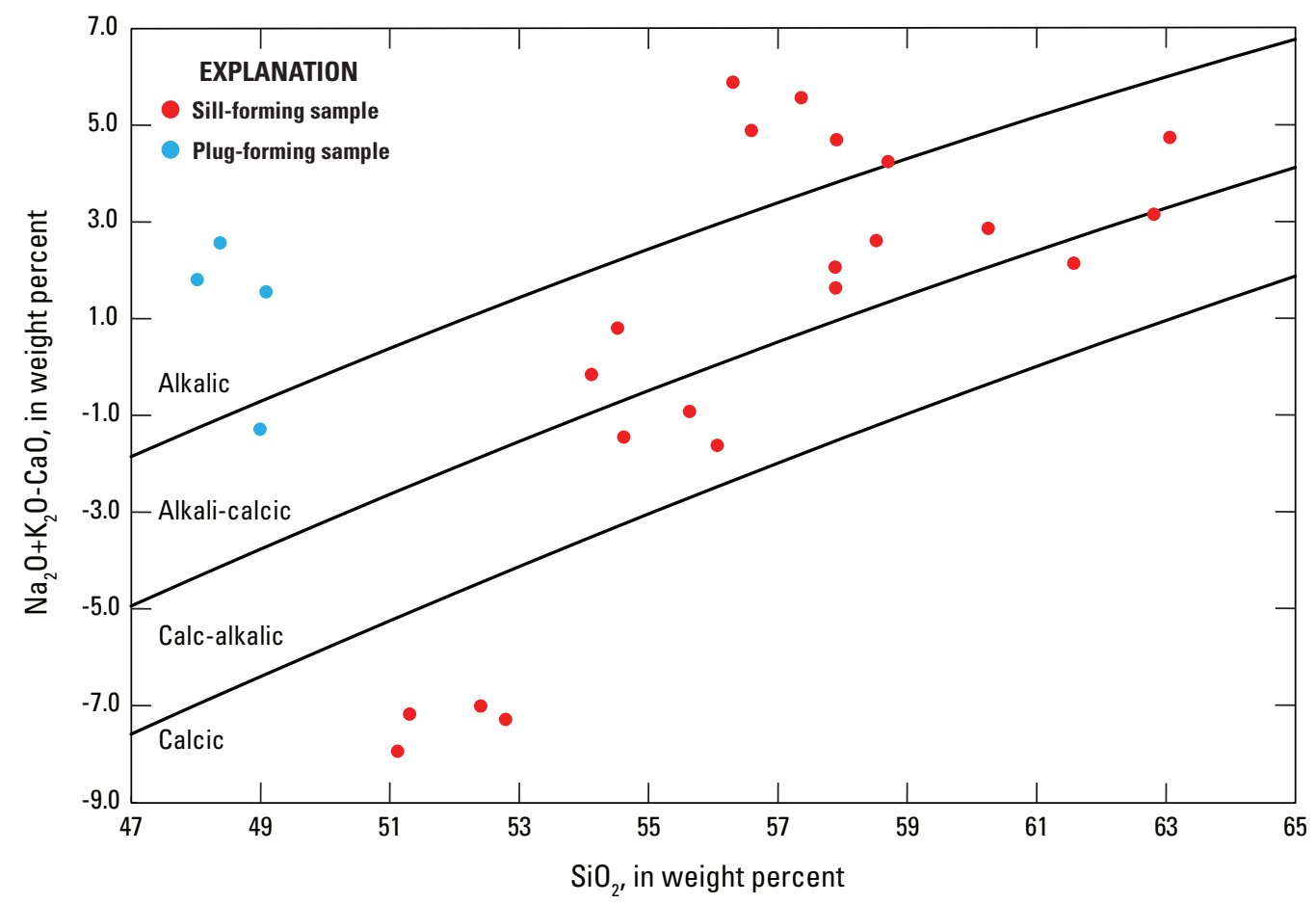

Figure 5. Variation diagram showing $\mathrm{Na}_{2} \mathrm{O}+\mathrm{K}_{2} \mathrm{O}-\mathrm{CaO}$ values versus $\mathrm{SiO}_{2}$ content among samples of igneous rocks peripheral to the Big Timber stock, Crazy Mountains, Montana. Boundaries between various rock series from Frost and others (2001).

Many geochemical features distinguish the compositions of the samples of the Ibex Mountain and plugs along the Shields River (fig. 1) from those of the sill-forming rocks. First, all four of these representative samples are composed of phonotephrite and have strongly alkaline compositions (fig. 4) relative to the alkaline-subalkaline dividing line of Irvine and Baragar (1971). Three of these four samples have agpaitic indices greater than 1 (fig. 2) and are therefore peralkaline; the fourth contains aegirine, which is likewise diagnostic of peralkaline magmas. The silica content of these rocks, about 48 to 49 weight percent, is significantly lower than that of most of the sill-forming rocks. Both the $\mathrm{Na}_{2} \mathrm{O}$ and $\mathrm{K}_{2} \mathrm{O}$ contents of these rocks are elevated, given their low silica contents, but they are especially sodic, with $\mathrm{Na}_{2} \mathrm{O}$ contents that range from about 5 to 8 weight percent (fig. 6). Like all other rocks in the Crazy Mountains, the strongly alkaline rocks are magnesian (fig. 3). Relative proportions of $\mathrm{Na}_{2} \mathrm{O}, \mathrm{K}_{2} \mathrm{O}$, and $\mathrm{CaO}$ in these rocks are consistent with alkalic to strongly alkali-calcic compositions (fig. 5). Relative to compositional trends depicted by all other alkaline to subalkaline rocks in the Crazy Mountains (fig. 6), the strongly alkaline rocks have low $\mathrm{TiO}_{2}$ and $\mathrm{CaO}$ abundances, high $\mathrm{Na}_{2} \mathrm{O}$ and $\mathrm{K}_{2} \mathrm{O}$ abundances, and remarkably high $\mathrm{P}_{2} \mathrm{O}_{5}$ abundances (fig. 6). Their $\mathrm{Al}_{2} \mathrm{O}_{3}$, $\mathrm{FeO}, \mathrm{MnO}$, and $\mathrm{MgO}$ abundances are approximately on trend with those of other alkaline to subalkaline rocks in the Crazy Mountains.

\section{Trace-Element Data}

Several aspects of trace-element data available for sillforming alkaline to subalkaline rocks of the Crazy Mountains are noteworthy. In particular, abundances of $\mathrm{Ba}$ (range, about $600-4,300$ parts per million [ppm]; average, about 2,200) and $\mathrm{Sr}$ (range, about 400-1,400 ppm; average, about 900) in these rocks are especially elevated relative to the concentrations of those elements in most igneous rocks (Turekian and Wedepohl, 1961). Rubidium (Rb) abundances in these rocks are relatively low, resulting in very low $\mathrm{Rb} / \mathrm{Sr}$ values (average, 0.06). Abundances of $\mathrm{Y}, \mathrm{Zr}, \mathrm{Nb}, \mathrm{La}, \mathrm{Ce}$, and $\mathrm{Nd}$ in these rocks are similar to those of other convergent-margin, broadly calcalkaline igneous rocks, such as those in the Andean, Kamchatka, and Central American volcanic arcs (Max Plank Institut für Chemie, 2010). Among the sill-forming rocks, Rb, Zr, $\mathrm{La}$, and $\mathrm{Ce}$ abundances increase systematically with increasing silica content; $\mathrm{Y}$ abundances decrease; and $\mathrm{Ba}, \mathrm{Sr}, \mathrm{Nb}$, and $\mathrm{Nd}$ abundances are uncorrelated with varying silica content. Most of the sill-forming rocks have relative abundances of $\mathrm{Rb}$ and $\mathrm{Y}+\mathrm{Nb}$ that are consistent with a genesis in a volcanic arc setting (fig. 7).

Most continental magmatic arc rocks have $\mathrm{Ba} / \mathrm{Nb}$ greater than 15 (Gill, 1981). The sill-forming rocks have $\mathrm{Ba} / \mathrm{Nb}$ values that average about 126, range upward to almost 240 , and do not vary systematically with respect to silica content. 

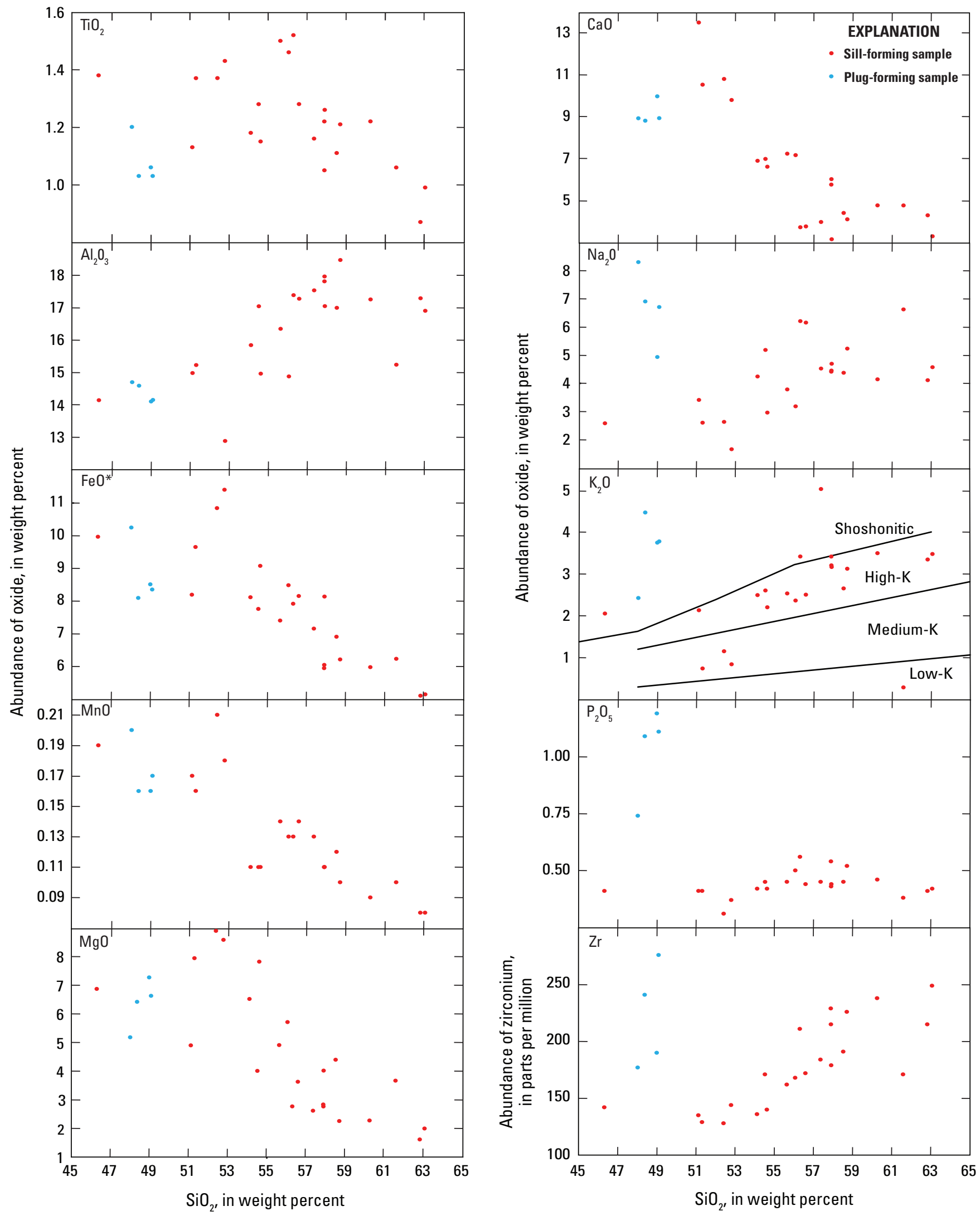

Figure 6. Variation diagrams showing abundances of major oxides in igneous rocks peripheral to the Big Timber stock, Crazy Mountains, Montana. All abundances in weight percent, except zirconium (in parts per million). Field boundaries on $\mathrm{K}_{2} \mathrm{O}$ versus $\mathrm{SiO}_{2}$ diagram from Le Maitre (2002); high-K-shoshonitic dividing line from Ewart (1982). 


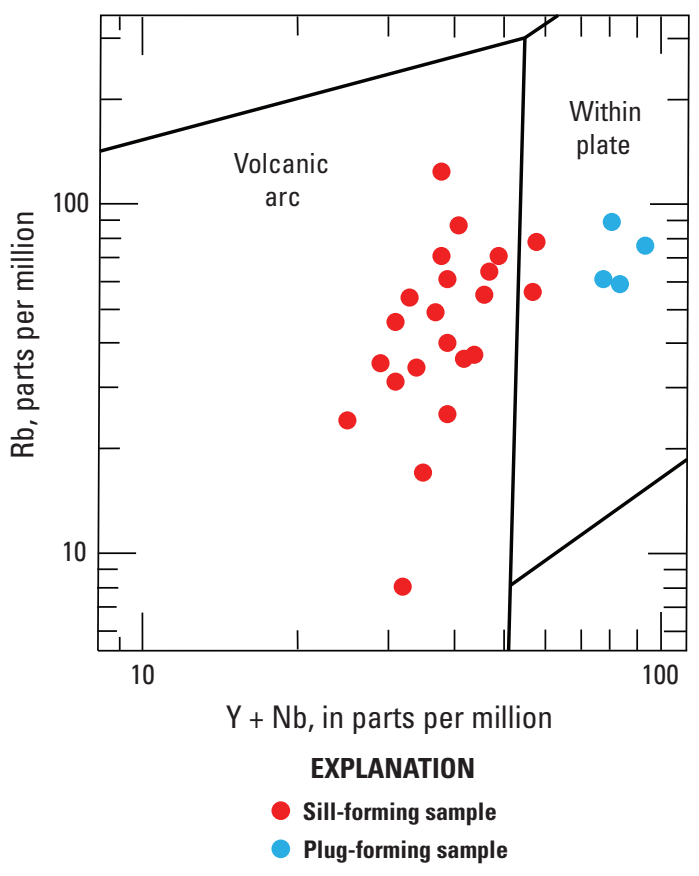

Figure 7. Trace-element, tectonic settingdiscrimination variation diagram showing the composition of igneous rocks peripheral to the Big Timber stock, Crazy Mountains, Montana. Tectonic setting-composition boundaries from Pearce and others (1984)

Elevated $\mathrm{Ba} / \mathrm{Nb}$ values have been associated with those mantle wedge magmas that derived subducted slab components through dehydration of the subducted-slab and attendant fluid flux-induced partial melting (Hawkesworth and others, 1995; Pearce and Peate, 1995; Cousens and others, 2008; Schmidt and others, 2008). Accordingly, highly elevated $\mathrm{Ba} / \mathrm{Nb}$ ratios and noteworthy large-ion lithophile element (Ba and $\mathrm{Sr}$ ) enrichments suggest significant involvement of a subducted-slab-derived fluid component in the petrogenesis of the magmas represented by the sill-forming rocks.

Trace-element characteristics of the strongly alkaline rocks are highly distinctive. Although $\mathrm{Ba}$ and $\mathrm{Sr}$ abundances in the sill-forming rocks are elevated (averaging about 3,200 and 2,700 ppm, respectively), those for the strongly alkaline rocks are even greater. Rubidium abundances in the strongly alkaline rocks are higher, averaging about $71 \mathrm{ppm}$; however, their average $\mathrm{Rb} / \mathrm{Sr}$ ratio is even lower (0.03) than that for the sill-forming rocks. Similarly, $\mathrm{Y}, \mathrm{Zr}$, and $\mathrm{Nb}$ abundances of the strongly alkaline rocks are significantly higher than those of the sill-forming rocks. The average $\mathrm{Zr}$ content of the strongly alkaline rocks (221 ppm) is lower than might be expected given their alkalinity and experimental work by Watson (1979), which demonstrated that the alkaline magmas, such as those represented by these rocks, can contain significantly greater zirconium concentrations before zircon saturation is achieved and zirconium concentrations become buffered. Finally, the light rare earth element ( $\mathrm{La}, \mathrm{Ce}$, and $\mathrm{Nd}$ ) abundances of the strongly alkaline rocks are strikingly elevated relative to those characteristic of other igneous rocks (Turekian and Wedepohl, 1961). These trace-element characteristics suggest that the petrogenetic history of these alkaline rocks was quite different from that responsible for magmas represented by the sill-forming rocks. A significant aspect of these distinctive characteristics is underscored by the fact that relative abundances of $\mathrm{Rb}$ and $\mathrm{Y}+\mathrm{Nb}$ for the strongly alkaline rocks coincide with the within-plate field on the trace-element, tectonic setting-discrimination variation diagram (fig. 7), whereas those for the sill-forming rocks are equivalent to volcanic arc compositions.

\section{Petrographic Characteristics}

Most samples of the sill-forming rocks described herein have similar petrographic characteristics; in contrast, samples of the strongly alkaline plug at Ibex Mountain are petrographically distinct and thus are described separately. Many of the sill-forming rocks contain either green or brown amphibole. Electron microprobe analyses of green and brown amphibole contained in the nearby Big Timber stock indicate that they are composed of magnesio-hornblende and magnesio-hastingsite, respectively (du Bray and Harlan, 1996). Optical features of the green amphibole in sill and Big Timber stock samples are indistinguishable, which suggests that the green amphibole in the sills is also magnesio-hornblende. Similarly, brown amphibole in the sills and the stock are optically indistinguishable, which suggests that brown amphibole in the sills is magnesio-hastingsite. The sill rocks are variably porphyritic. Phenocryst abundances range from 0 to 65 percent, averaging about 20 percent. Color index ranges from 1 to 35 percent, averaging about 13 percent. Fine- to medium-grained phenocryst assemblages include combinations of plagioclase, magnesio-hornblende, magnesio-hastingsite, clinopyroxene, and rare biotite in a fine-grained groundmass composed of combinations of plagioclase, magnesio-hornblende, magnesiohastingsite, clinopyroxene, opaque iron-titanium oxides, and variably devitrified glass. The groundmass minerals form intersertal intergrowths in most samples, although in several samples the groundmass consists of intergranular intergrowths.

Among samples of dikes associated with the Big Timber stock, the composition of the mafic silicate minerals is strongly correlated with whole-rock composition (du Bray and others, 2006); basaltic trachyandesite dikes are dominated by clinopyroxene, low-silica trachyandesite dikes contain clinopyroxene and magnesio-hastingsite, high-silica trachyandesite to low-silica trachydacite dikes contain magnesiohastingsite, and high-silica trachydacite to rhyolite dikes contain biotite and magnesio-hornblende. The composition of the mafic silicate minerals contained in the sill-forming rocks correlate similarly, but less systematically, with whole-rock composition. Accessory minerals in the sill-forming rocks are 
rare, though apatite was identified in several samples. The groundmass of many samples contains secondary calcite and (or) chlorite related to post magmatic alteration of many of these rocks. Similarly, many primary phenocrysts are variably altered and have been replaced by calcite and clay or sericite.

The plug at Ibex Mountain is composed of rock that ranges from holocrystalline and equigranular (sample 202338) to porphyritic with a hyalophitic groundmass (sample 002W92). Pale green clinopyroxene is the dominant mineral in both of these samples; other mafic silicate minerals include tan to distinctly red-brown biotite and trace amounts of subhedral olivine. Clinopyroxene in sample 202338 is overgrown by distinctive emerald-green aegirine rims, and in both Ibex Mountain samples is distinguished by a well-developed sieve texture. These rocks lack quartz and feldspar but, befitting their strongly alkaline character, they contain nepheline, which forms anhedral, interstitial grains in sample 202338 and euhedral phenocrysts in sample 002W92. Some nepheline is partly replaced by and (or) overgrown by acicular sprays of zeolite minerals. Sample 002W92 is further distinguished by the presence of cancrinite, which forms small discrete grains and overgrowths on nepheline crystals. The occurrence of cancrinite in strongly alkaline rocks, particularly in the northern Crazy Mountains, was highlighted by the detailed investigations of Simms (1966). Apatite is a characteristic accessory constituent of the Ibex Mountain plug.

\section{Synthesis}

The most significant finding derived from data presented herein is that the geochemical and petrographic characteristics of the sill-forming rocks are indistinguishable from those of the Big Timber stock and its radial dike swarm. Consequently, the central stock, associated radial dikes, and surrounding sills seem to be part of a single, coeval magmatic episode in the Crazy Mountains. By analogy, other still unsampled and undocumented sill-forming intrusions peripheral to and south and east of the Big Timber stock are probably also composed of rock related to magmatism responsible for formation of the Big Timber stock. In contrast, the small amount of data for the plug-forming rocks at Ibex Mountain and along the Shields River indicate that the geochemistry and petrography of these rocks are significantly different from those of the sill-forming rocks but remarkably similar to those of other strongly alkaline igneous rocks exposed north and west of the Big Timber stock.

Characteristics of the sill-forming intrusions are in accord with their petrogenesis in a subduction-related setting, as is also true for the Big Timber stock and its radial dike swarm (du Bray and Harlan, 1996). Unusual trace-element abundances, especially elevated concentrations of $\mathrm{Ba}$ and $\mathrm{Sr}$, are consistent with significant crustal inputs through assimilation and (or) magmatism involving noteworthy inputs derived from fluids released during devolatilization of the downgoing, subducted slab. Finally, the geospatial and temporal coincidence of strongly alkaline and alkaline to subalkaline magmas in the Crazy Mountains remains something of a petrologic paradox.

\section{Acknowledgments}

Data compilation undertaken for this study was conducted as part of the mineral resource assessment of Custer and Gallatin National Forests funded by the U.S. Geological Survey Mineral Resources Program. Constructive reviews by Ryan D. Taylor and Matthew Granitto are much appreciated and helped clarify data presentation.

\section{References Cited}

Cousens, B.L., Prytulak, Julie, Henry, C.D., Alcazar, Al, and Brownrigg, Tim, 2008, Geology, geochronology, and geochemistry of the Miocene-Pliocene ancestral Cascades arc, northern Sierra Nevada, California and Nevada-The roles of the upper mantle, subducting slab, and the Sierra Nevada lithosphere: Geosphere, v. 4, p. 814-828.

du Bray, E.A., Elliott, J.E., Wilson, A.B., Van Gosen, B.S., and Rosenberg, L.A., 1993, Geologic map of the Big Timber stock and vicinity, southern Crazy Mountains, Sweet Grass and Park Counties, south-central Montana: U.S. Geological Survey Miscellaneous Field Investigations Series Map MF-2253, scale 1:24,000.

du Bray, E.A., and Harlan, S.S., 1996, The Eocene Big Timber stock, south-central Montana-Development of extensive compositional variation in an arc-related intrusion by side-wall crystallization and cumulate glomerocryst remixing: Geological Society of America Bulletin, v. 108, p. 1404-1424.

du Bray, E.A., Harlan, S.S., and Wilson, A.B., 2006, Petrology of the Crazy Mountains dike swarm and geochronology of associated sills, south-central Montana: U.S. Geological Survey Professional Paper 1715, 21 p.

Dudas, F.O., 1990, Petrogenesis and mantle source of igneous rocks in the Crazy Mountains, Montana: University Park, Pennsylvania State University, Ph.D. thesis, 442 p.

Dudas, F.O., 1991, Geochemistry of igneous rocks from the Crazy Mountains, Montana, and tectonic models for the Montana alkalic province: Journal of Geophysical Research, v. 96, p. 13261-13277.

Elsass, Françoise, and du Bray, E.A., 1982, Energy-dispersive X-ray fluorescence spectrometry with the Kevex 7000 system: Saudi Arabia, Deputy Ministry of Mineral Resources Open-File Report USGS-OF-02-52, 53 p. 
Ewart, Anthony, 1982, The mineralogy and petrology of Tertiary-Recent orogenic volcanic rocks with special reference to the andesitic-basaltic compositional range, in Thorpe, R.S., ed., Andesites: New York, John Wiley and Sons, p. 25-87.

Farmer, G.L., Glazner, A.F., and Manley, C.R., 2002, Did lithospheric delamination trigger late Cenozoic potassic volcanism in the southern Sierra Nevada, California?: Geological Society of America Bulletin, v. 114, p. 754-768.

Frost, B.R., Barnes, C.G., Collins, W.J., Arculus, R.J., Ellis, D.J., and Frost, C.D., 2001, A geochemical classification for granitic rocks: Journal of Petrology, v. 42, p. 2033-2048.

Gill, J.B., 1981, Orogenic andesites and plate tectonics: New York, Springer-Verlag, $390 \mathrm{p}$.

Hawkesworth, Chris; Turner, Simon; Gallagher, Kerry; Hunter, Arlene; Bradshaw, Tim; and Rogers, Nick, 1995, Calc-alkaline magmatism, lithospheric thinning and extension in the Basin and Range: Journal of Geophysical Research, v. 100, p. 10271-10286.

Irvine, T.N., and Baragar, W.R.A., 1971, A guide to the chemical classification of the common volcanic rocks: Canadian Journal of Earth Sciences, v. 8, p. 523-548.

Le Maitre, R.W., 2002, Igneous rocks-A classification and glossary of terms ( $2 \mathrm{~d}$ ed.): Cambridge, United Kingdom, Cambridge University Press, 236 p.

Max Plank Institut für Chemie, 2010, Geochemistry of rocks of the oceans and continents (GEOROC) [Query by geological setting — convergent margins]: Mainz, Germany, Max Plank Institut für Chemie, accessed June 10, 2014, at http://georoc.mpch-mainz.gwdg.de/georoc/.

Pearce, J.A., Harris, N.B.W., and Tindle, A.G., 1984, Trace element discrimination diagrams for the tectonic interpretation of granitic rocks: Journal of Petrology, v. 25, p. 956-983.

Pearce, J.A., and Peate, D.W., 1995, Tectonic implications of the composition of volcanic arc magmas: Annual Review of Earth and Planetary Sciences, v. 23, p. 251-285.

Roberts, A.E., 1972, Cretaceous and early Tertiary depositional and tectonic history of the Livingston area, southwestern Montana: U.S. Geological Survey Professional Paper 526-C, $120 \mathrm{p}$.

Schmidt, M.E., Grunder, A.L., and Rowe, M.C., 2008, Segmentation of the Cascade arc as indicated by $\mathrm{Sr}$ and $\mathrm{Nd}$ isotopic variation among diverse primitive basalts: Earth and Planetary Science Letters, v. 266, p. 166-181.

Shand, S.J., 1951, Eruptive rocks: New York, John Wiley, $488 \mathrm{p}$.
Simms, F.E., 1966, The igneous petrology, geochemistry, and structural geology of part of the northwestern Crazy Mountains, Montana: Cincinnati, Ohio, University of Cincinnati, Ph.D. thesis, 339 p.

Starmer, R.J., 1972, The distribution and geochemistry of the Big Timber dike swarm, Crazy Mountains, Montana: Cincinnati, Ohio, University of Cincinnati, Ph.D. thesis, 90 p.

Taggart, J.E., Lindsay, J.R., Scott, B.A., Vivit, D.V., Bartel, A.J., and Stewart, K.C., 1987, Analysis of geologic materials by X-ray fluorescence spectrometry, Chapter E of Baedecker, P.A., ed., Methods for geochemical analysis: U.S. Geological Survey Bulletin 1770, p. E1-E19.

Tappe, John, 1966, The chemistry, petrology, and structure of the Big Timber igneous complex, Crazy Mountains, Montana: Cincinnati, Ohio, University of Cincinnati, Ph.D. thesis, $134 \mathrm{p}$.

Turekian, K.K., and Wedepohl, K.H., 1961, Distribution of the elements in some major units of the Earth's crust: Geological Society of America Bulletin, v. 72, p. 175-192.

Watson, E.B., 1979, Zircon saturation in felsic liquidsExperimental results and applications to trace element geochemistry: Contributions to Mineralogy and Petrology, v. 70, p. 407-419.

Wolff, J.E., 1938, Igneous rocks of the Crazy Mountains, Montana: Geological Society of America Bulletin, v. 49, p. 1569-1626.

Yager, D.B., and Quick, J.E., 1992, SUPERXAP manual: U.S. Geological Survey Open-File Report 92-13, 45 p.

Publishing support provided by:

Denver Publishing Service Center

For more information concerning this publication, contact:

Center Director, USGS Central Mineral and

Environmental Resources Science Center

Box 25046, Mail Stop 973

Denver, CO 80225

(303) 236-1562

Or visit the Central Mineral and Environmental Resources Science Center Web site at: http://minerals.cr.usgs.gov/ 
Appendixes 
Appendix 1. Status and treatment of samples of sills and plugs peripheral to the Big Timber stock, Crazy Mountains, Montana. (Click here to open in Microsoft Excel.)

[See table 1 for an explanation of data fields. Chem, chemical analysis; TS, thin section; LOI, loss on ignition; $\mathrm{K}_{2} \mathrm{O}$, potassium oxide]

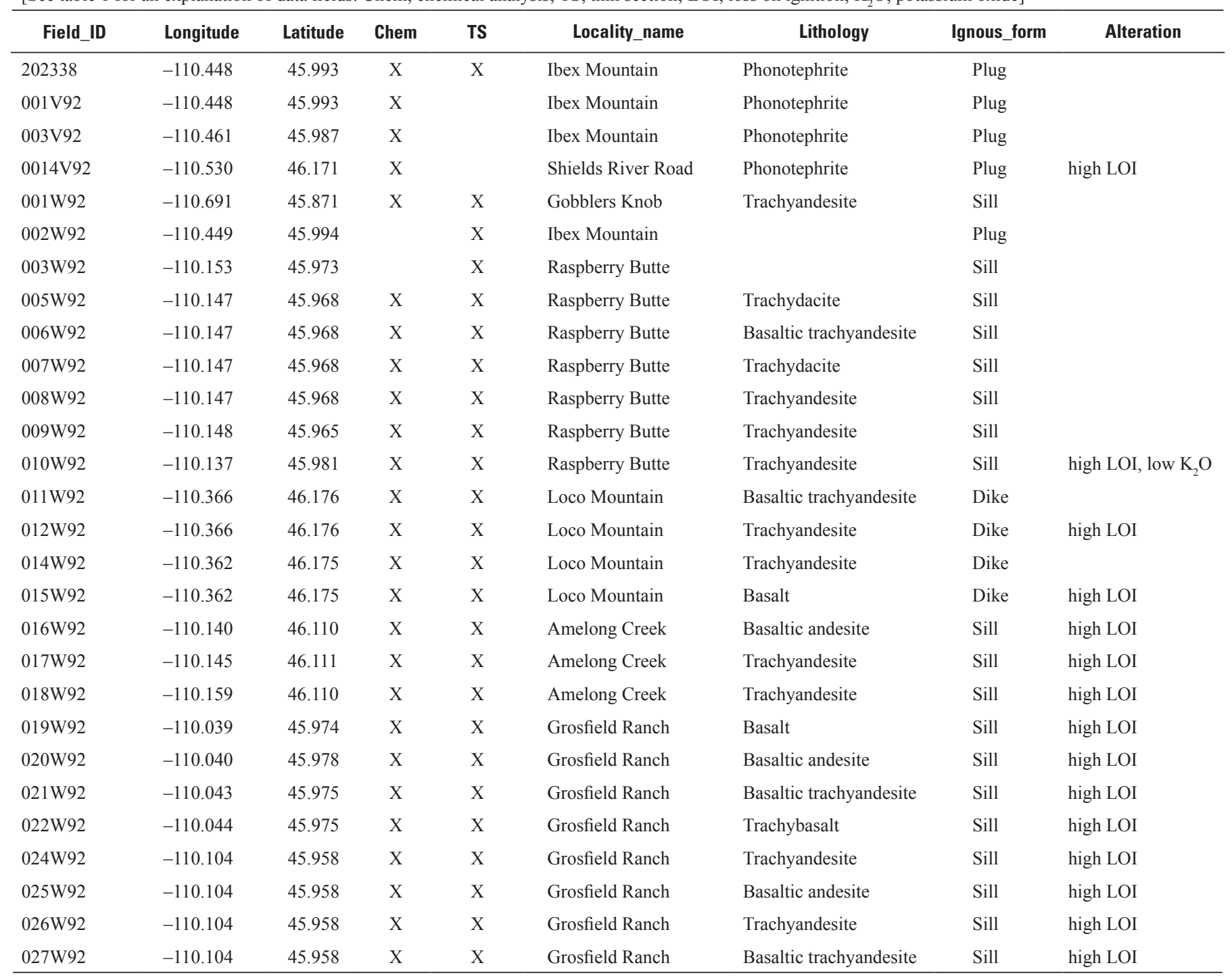


Appendix 2. Geochemical and petrographic data for samples of sills and plugs peripheral to the Big Timber stock, Crazy Mountains, Montana. (Click here to open in Microsoft Excel.)

[See table 2 for an explanation of data fields. mm, millimeter; pct, percent; ppm, parts per million; LOI, loss on ignition; Abd, abundance; phenos, phenocrysts; Ags, average grain size; Mgs, maximum grain size; Xl, crystallinity. Texture: Aph, aphanitic; E, equigranular; Hc, holocrystalline; Hy, hyalophitic; I, intersertal; P, porphyritic; S, seriate; T, trachytic. Accessory minerals: Ap, apatite, Ttn, titanite. Crystallinity: A, anhedral; E, euhedral; S, subhedral]

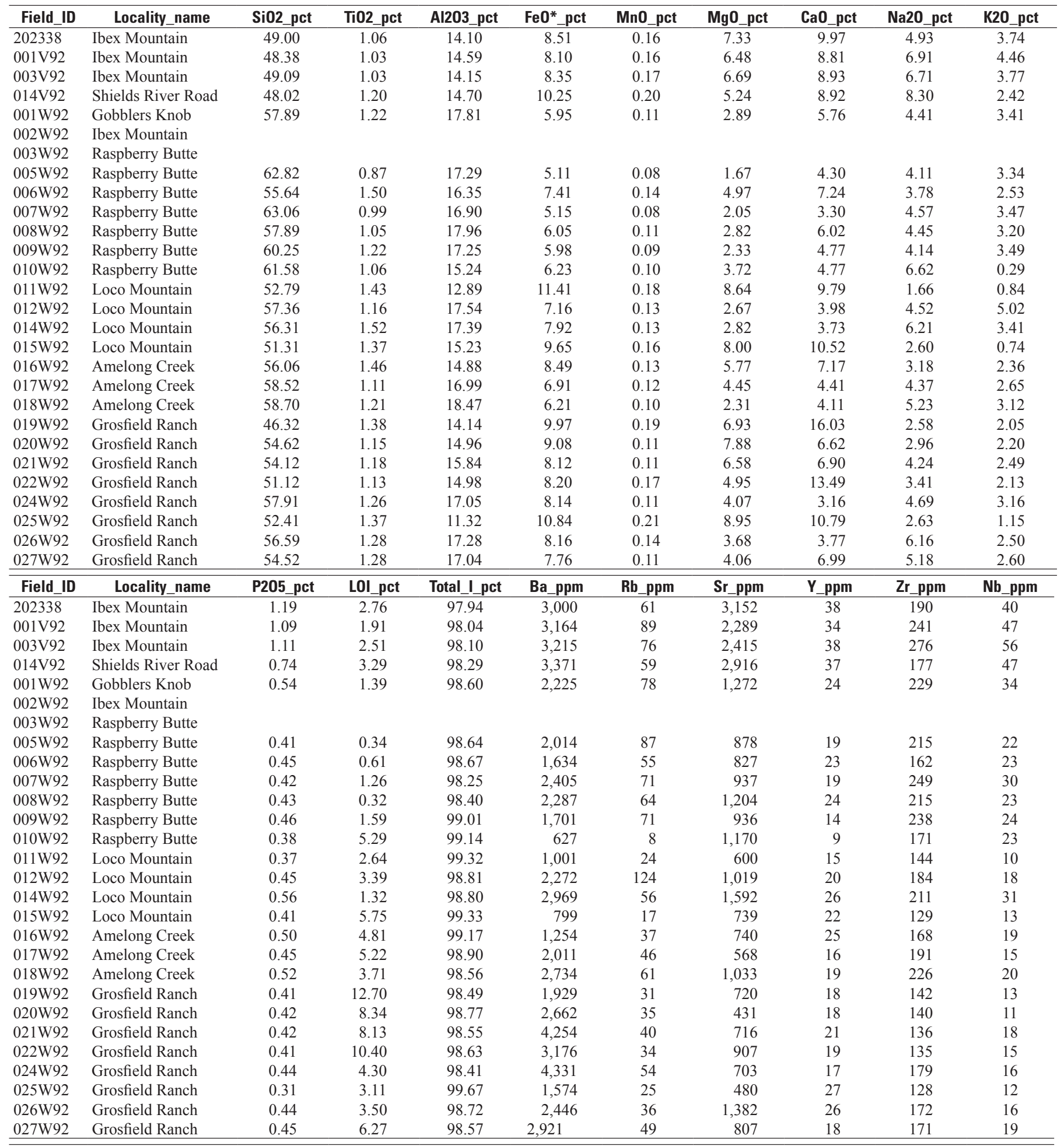


Appendix 2. Geochemical and petrographic data for samples of sills and plugs peripheral to the Big Timber stock, Crazy Mountains, Montana.-Continued

[See table 2 for an explanation of data fields. mm, millimeter; pct, percent; ppm, parts per million; LOI, loss on ignition; Abd, abundance; phenos, phenocrysts; Ags, average grain size; Mgs, maximum grain size; Xl, crystallinity. Texture: Aph, aphanitic; E, equigranular; Hc, holocrystalline; Hy, hyalophitic; I, intersertal; P, porphyritic; S, seriate; T, trachytic. Accessory minerals: Ap, apatite, Ttn, titanite. Crystallinity: A, anhedral; E, euhedral; S, subhedral]

\begin{tabular}{|c|c|c|c|c|c|c|c|c|c|c|}
\hline Field_ID & Locality_name & Th_ppm & Ga_ppm & La_ppm & Ce_ppm & Nd_ppm & Cu_ppm & Pb_ppm & Zn_ppm & Sn_ppm \\
\hline 202338 & Ibex Mountain & & 12 & 164 & 236 & 137 & 122 & & 74 & 5 \\
\hline $001 \mathrm{~V} 92$ & Ibex Mountain & & 25 & 161 & 251 & 112 & 184 & 25 & 67 & \\
\hline 003V92 & Ibex Mountain & & 24 & 152 & 273 & 118 & 23 & 56 & 137 & 5 \\
\hline 014V92 & Shields River Road & & 17 & 151 & 283 & 170 & 197 & 22 & 156 & 2 \\
\hline $001 \mathrm{~W} 92$ & Gobblers Knob & & 32 & 88 & 155 & 42 & 11 & 18 & 88 & 2 \\
\hline 002W92 & Ibex Mountain & & & & & & & & & \\
\hline 003W92 & Raspberry Butte & & & & & & & & & \\
\hline $005 \mathrm{~W} 92$ & Raspberry Butte & & 14 & 57 & 108 & 54 & & & 71 & 7 \\
\hline 006W92 & Raspberry Butte & & & 41 & 93 & 36 & & 22 & 78 & \\
\hline 007W92 & Raspberry Butte & & 21 & 76 & 111 & 65 & 28 & 10 & 42 & \\
\hline 008W92 & Raspberry Butte & & 14 & 62 & 113 & 33 & & 47 & 77 & 5 \\
\hline 009W92 & Raspberry Butte & & 20 & 48 & 94 & 49 & 9 & 24 & 69 & 7 \\
\hline 010W92 & Raspberry Butte & & 19 & 57 & 96 & 40 & 29 & 28 & 74 & \\
\hline 011W92 & Loco Mountain & & 9 & 20 & 60 & 40 & 28 & 32 & 99 & \\
\hline 012W92 & Loco Mountain & & 30 & 47 & 70 & 27 & 24 & 10 & 54 & \\
\hline 014W92 & Loco Mountain & & 26 & 43 & 83 & 62 & 2 & & 104 & 2 \\
\hline $015 \mathrm{~W} 92$ & Loco Mountain & & 26 & 32 & 67 & 26 & 55 & 30 & 79 & \\
\hline 016W92 & Amelong Creek & & & 38 & 76 & 33 & 25 & 14 & 47 & 5 \\
\hline 017W92 & Amelong Creek & & 9 & 51 & 76 & 46 & 25 & 35 & 62 & 2 \\
\hline 018W92 & Amelong Creek & & 9 & 73 & 69 & 44 & 65 & 10 & 60 & \\
\hline 019W92 & Grosfield Ranch & & 25 & 48 & 78 & 51 & 49 & 29 & 93 & \\
\hline 020W92 & Grosfield Ranch & & 16 & 48 & 79 & 49 & 6 & 4 & 58 & \\
\hline $021 \mathrm{~W} 92$ & Grosfield Ranch & & 19 & 36 & 74 & 29 & 22 & 42 & 60 & \\
\hline 022W92 & Grosfield Ranch & & 19 & 63 & 72 & 50 & 16 & 17 & 78 & \\
\hline 024W92 & Grosfield Ranch & 10 & & 44 & 50 & 22 & 8 & 26 & 80 & \\
\hline $025 \mathrm{~W} 92$ & Grosfield Ranch & 15 & 18 & 25 & 50 & 52 & 27 & 33 & 111 & \\
\hline 026W92 & Grosfield Ranch & & & 33 & 80 & 36 & 63 & 20 & 46 & \\
\hline 027W92 & Grosfield Ranch & 17 & 13 & 46 & 68 & 54 & 11 & 25 & 85 & \\
\hline Field_ID & Locality_name & W_ppm & As_ppm & & Sb_ppm & Abd_PI_phenos & Abd_G & Imph_phenos & Abd_Bri & ph_phenos \\
\hline 202338 & Ibex Mountain & & 16 & & 0.4 & & & & & \\
\hline $001 \mathrm{~V} 92$ & Ibex Mountain & & 6 & & 0.3 & & & & & \\
\hline 003V92 & Ibex Mountain & & & & 0.2 & & & & & \\
\hline $014 \mathrm{~V} 92$ & Shields River Road & & 14 & & 0.4 & & & & & \\
\hline $001 \mathrm{~W} 92$ & Gobblers Knob & & 8 & & 0.2 & 20 & & 5 & & \\
\hline 002W92 & Ibex Mountain & & & & & & & & & \\
\hline 003W92 & Raspberry Butte & & & & & 15 & & & & \\
\hline $005 \mathrm{~W} 92$ & Raspberry Butte & & 12 & & 0.9 & 25 & & & & \\
\hline 006W92 & Raspberry Butte & & 2 & & 0.4 & 3 & & 8 & & \\
\hline 007W92 & Raspberry Butte & & & & 0.7 & 15 & & 4 & & \\
\hline 008W92 & Raspberry Butte & & & & 0.4 & 15 & & 3 & & \\
\hline 009W92 & Raspberry Butte & 2 & & & 0.6 & 15 & & 2 & & \\
\hline 010W92 & Raspberry Butte & & 28 & & 0.6 & 4 & & & & \\
\hline 011W92 & Loco Mountain & & & & 0.4 & & & & & \\
\hline 012W92 & Loco Mountain & & & & 0.4 & 7 & & & & \\
\hline 014W92 & Loco Mountain & & 16 & & 1.2 & 40 & & & & \\
\hline 015 W92 & Loco Mountain & 2 & 0 & & 0.6 & 7 & & & & \\
\hline 016W92 & Amelong Creek & & 13 & & 0.3 & 10 & & & & \\
\hline 017W92 & Amelong Creek & & & & 0.3 & 25 & & & & \\
\hline 018W92 & Amelong Creek & & & & 0.4 & 25 & & & & \\
\hline 019W92 & Grosfield Ranch & & 20 & & & 1 & & & & \\
\hline 020W92 & Grosfield Ranch & & 27 & & & & & & & \\
\hline $021 \mathrm{~W} 92$ & Grosfield Ranch & 4 & 10 & & 0.3 & & & & & \\
\hline 022W92 & Grosfield Ranch & & 8 & & 0.1 & & & & & \\
\hline 024W92 & Grosfield Ranch & & 15 & & 0.3 & 3 & & & & \\
\hline 025W92 & Grosfield Ranch & & 3 & & 0.6 & 1 & & & & \\
\hline 026W92 & Grosfield Ranch & 1 & & & 0.2 & 5 & & & & \\
\hline 027W92 & Grosfield Ranch & & 19 & & 0.5 & 1 & & & & \\
\hline
\end{tabular}


Appendix 2. Geochemical and petrographic data for samples of sills and plugs peripheral to the Big Timber stock, Crazy Mountains, Montana.-Continued

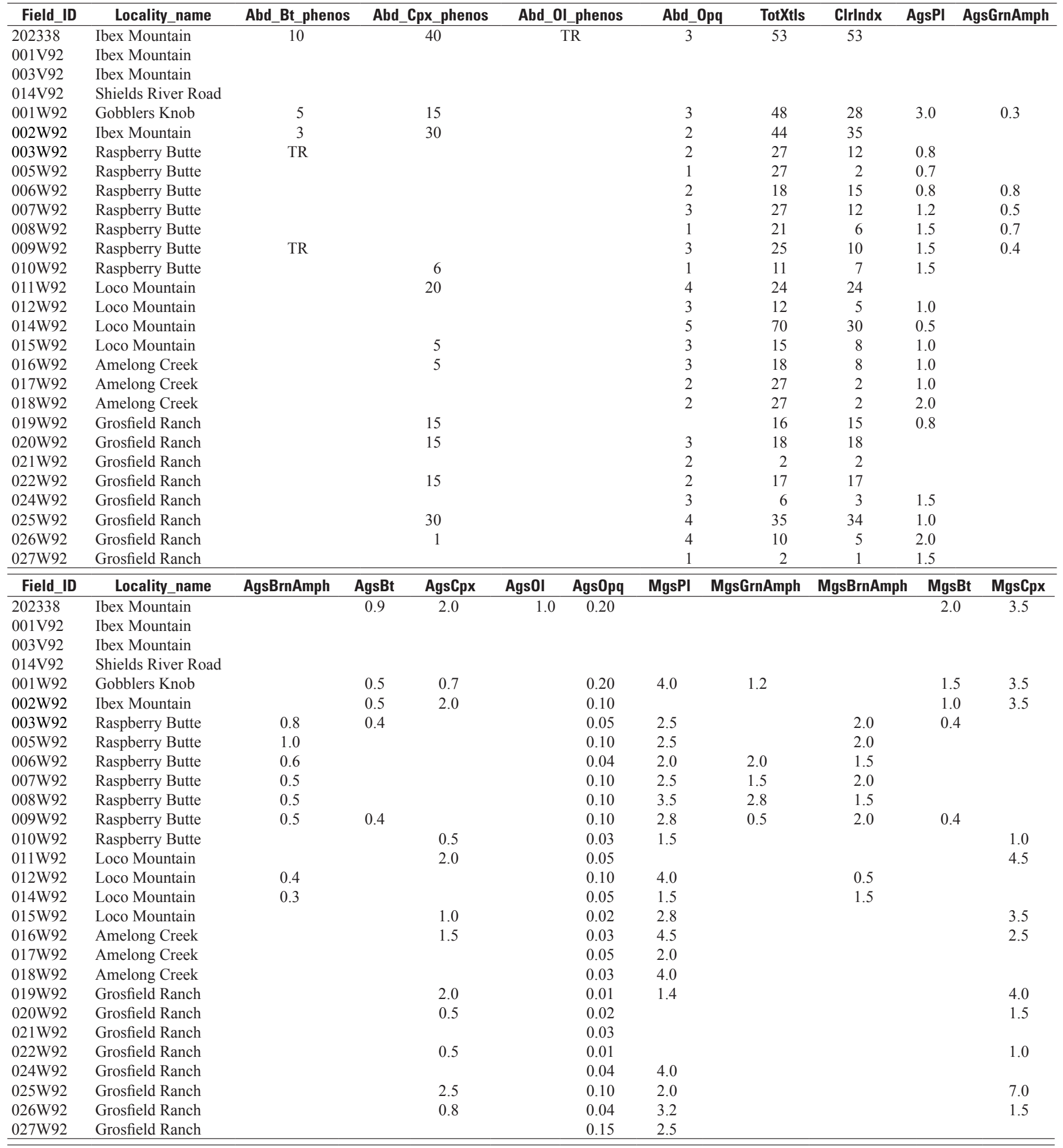


Appendix 2. Geochemical and petrographic data for samples of sills and plugs peripheral to the Big Timber stock, Crazy Mountains, Montana.-Continued

[See table 2 for an explanation of data fields. mm, millimeter; pct, percent; ppm, parts per million; LOI, loss on ignition; Abd, abundance; phenos, phenocrysts; Ags, average grain size; Mgs, maximum grain size; Xl, crystallinity. Texture: Aph, aphanitic; E, equigranular; Hc, holocrystalline; Hy, hyalophitic; I, intersertal; P, porphyritic; S, seriate; T, trachytic. Accessory minerals: Ap, apatite, Ttn, titanite. Crystallinity: A, anhedral; E, euhedral; S, subhedral]

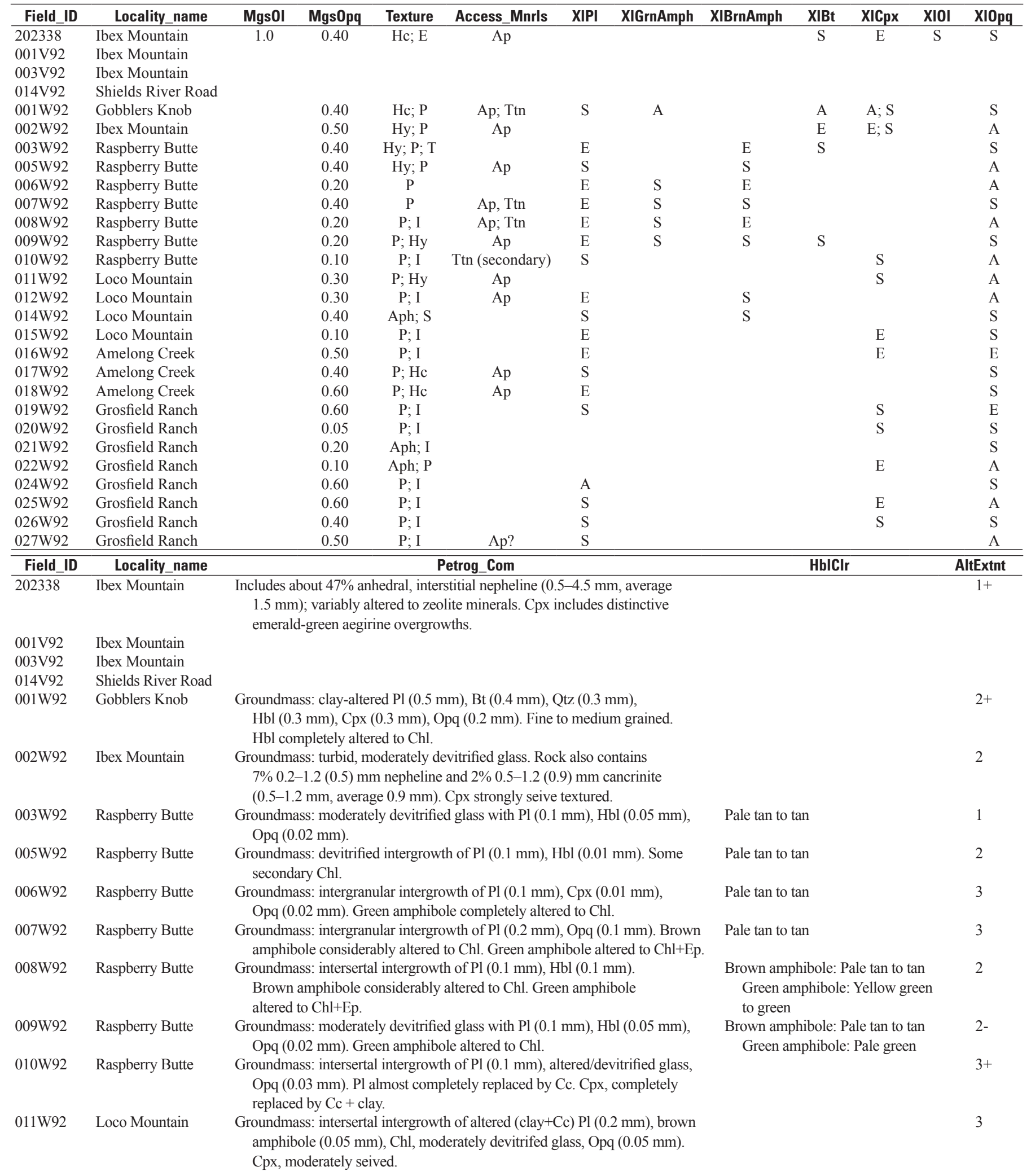


Appendix 2. Geochemical and petrographic data for samples of sills and plugs peripheral to the Big Timber stock, Crazy Mountains, Montana.-Continued

[See table 2 for an explanation of data fields. mm, millimeter; pct, percent; ppm, parts per million; LOI, loss on ignition; Abd, abundance; phenos, phenocrysts; Ags, average grain size; Mgs, maximum grain size; Xl, crystallinity. Texture: Aph, aphanitic; E, equigranular; Hc, holocrystalline; Hy, hyalophitic; I, intersertal; P, porphyritic; S, seriate; T, trachytic. Accessory minerals: Ap, apatite, Ttn, titanite. Crystallinity: A, anhedral; E, euhedral; S, subhedral]

\begin{tabular}{|c|c|c|c|c|}
\hline Field_ID & Locality_name & Petrog_Com & HbIClr & AltExtnt \\
\hline 014W92 & Loco Mountain & $\begin{array}{l}\text { Groundmass: intersertal intergrowth of } \mathrm{Pl}(0.1 \mathrm{~mm}) \text {, brown amphibole } \\
(0.1 \mathrm{~mm}) \text {, moderately devitrified glass, } \mathrm{Opq}(0.03 \mathrm{~mm}) .\end{array}$ & Pale tan to tan & 2 \\
\hline 015W92 & Loco Mountain & $\begin{array}{l}\text { Groundmass: intersertal intergrowth of Pl }(0.1 \mathrm{~mm}) \text {, brown amphibole } \\
(0.05 \mathrm{~mm}), \mathrm{Opq}(0.03 \mathrm{~mm}) \text {. Abundant secondary Cc; some secondary Chl. }\end{array}$ & & 3 \\
\hline 016W92 & Amelong Creek & $\begin{array}{l}\text { Groundmass: intersertal intergrowth of } \mathrm{Pl}(0.1 \mathrm{~mm}) \text {, brown amphibole } \\
\quad(0.1 \mathrm{~mm}), \mathrm{Opq}(0.03 \mathrm{~mm}) \text {. Abundant secondary Cc; some secondary Chl. }\end{array}$ & & $2+$ \\
\hline 018W92 & Amelong Creek & $\begin{array}{l}\text { Groundmass: intersertal intergrowth of } \mathrm{Pl}(0.2 \mathrm{~mm}), \mathrm{Hbl}(0.1 \mathrm{~mm}), \mathrm{Qtz} \\
(0.05 \mathrm{~mm}), \mathrm{Opq}(0.02 \mathrm{~mm}) \text {. Abundant secondary Chl. }\end{array}$ & & 3 \\
\hline 019W92 & Grosfield Ranch & $\begin{array}{l}\text { Groundmass: intersertal intergrowth of } \mathrm{Pl}(0.1 \mathrm{~mm}) \text {, brown amphibole } \\
(0.05 \mathrm{~mm}), \mathrm{Opq}(0.01 \mathrm{~mm}) \text {. Abundant secondary Chl and Qtz. }\end{array}$ & & 3 \\
\hline 020W92 & Grosfield Ranch & $\begin{array}{l}\text { Groundmass: intersertal intergrowth of } \mathrm{Pl}(0.1 \mathrm{~mm}), \mathrm{Hbl}(0.05 \mathrm{~mm}) \text {, turbid } \\
\text { glass, Opq }(0.02 \mathrm{~mm}) \text {. Cpx completely altered to Chl+clay. Abundant } \\
\text { secondary Chl and Qtz. }\end{array}$ & & $3+$ \\
\hline 022W92 & Grosfield Ranch & $\begin{array}{l}\text { Groundmass: aphanitic intergrowth of } \mathrm{Pl}(0.05 \mathrm{~mm}), \mathrm{Opq}(0.01 \mathrm{~mm}) \text {, } \\
\text { altered/devitrified glass. }\end{array}$ & & 4 \\
\hline 024W92 & Grosfield Ranch & $\begin{array}{l}\text { Groundmass: intersertal intergrowth of Pl }(0.4 \mathrm{~mm}), \mathrm{Hbl}(0.1 \mathrm{~mm}) \text {, } \\
\text { Opq }(0.05 \mathrm{~mm}) \text {. Abundant secondary Cc. }\end{array}$ & & $2+$ \\
\hline 025W92 & Grosfield Ranch & $\begin{array}{l}\text { Groundmass: intersertal intergrowth of Pl }(0.2 \mathrm{~mm}), \mathrm{Hbl}(0.2 \mathrm{~mm}) \text {, } \\
\text { Opq }(0.05 \mathrm{~mm}), \mathrm{Cpx}(0.1 \mathrm{~mm}) .\end{array}$ & & $2-$ \\
\hline 026W92 & Grosfield Ranch & $\begin{array}{l}\text { Groundmass: intersertal intergrowth of } \mathrm{Pl}(0.3 \mathrm{~mm}), \mathrm{Hbl}(0.1 \mathrm{~mm}), \mathrm{Cpx} \\
\quad(0.1 \mathrm{~mm}), \mathrm{Opq}(0.04 \mathrm{~mm}) .\end{array}$ & & 3 \\
\hline 027W92 & Grosfield Ranch & $\begin{array}{l}\text { Groundmass: intersertal intergrowth of } \mathrm{Pl}(0.2 \mathrm{~mm}), \mathrm{Hbl}(0.1 \mathrm{~mm}), \mathrm{Opq} \\
(0.04 \mathrm{~mm}) \text {, devitrified glass (?). Abundant secondary Cc. Hbl in ground- } \\
\text { mass altered to Chl. }\end{array}$ & & 3 \\
\hline
\end{tabular}




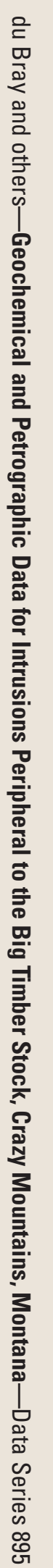

